\title{
Pengaruh integrasi intervensi gizi dan stimulasi tumbuh kembang terhadap peningkatan berat badan dan perkembangan balita kurus
}

Effect of integration of nutrition intervention and development stimulation on weight gain and development of wasted children

\section{Bunga Astria Paramashanti ${ }^{1}$, Sulistyawati ${ }^{2}$}

${ }^{1}$ Program Studi Gizi, Universitas Alma Ata, Yogyakarta

${ }^{2}$ Program Studi Ners, Universitas Alma Ata, Yogyakarta

\begin{abstract}
Background: Indonesia has faced the problem where double burden malnutrition increasing. On the other hand, malnutrition in children may affect the development both in early childhood and the quality of human capital in later life. Objective: This study aimed to examine the effect of integration of nutrition intervention and development stimulation on weight gain and development of wasted children. Method: Design used in this study was quasi-experimental with pre- and post-test control group. Subjects were 38 children under-five resided in Sedayu Subdistrict. Sampels were selected by using total sampling of children under-five in community feeding center, meanwhile controls were children under-five selected from integrated health posts in another villages with the ratio of 1:1. Interventions given were education, development stimulation and food supplementation package distributed by the community health workers whom were given capacity building. Analysis used were Mann-Whitney U and Wilcoxon Signed Rank tests at the level of significance 0,05. Results: Children in intervention groups gained their weight significantly from before

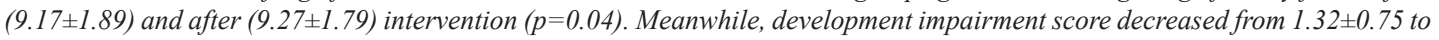
$0.42 \pm 0.61$ significantly $(p=0.00)$. Conclusion: Intervention package containing nutrition and development education, development stimulation and supplementary food through community feeding center (CFC) sucessfully increased body weight and development of wasted children significantly.
\end{abstract}

KEY WORDS: body weight; children under-five; development stimulation; nutrition intervention; supplementary food

\begin{abstract}
ABSTRAK
Latar belakang: Indonesia mengalami masa transisi yaitu kejadian double burden malnutrition semakin meningkat. Di sisi lain, malnutrisi pada anak juga berdampak pada perkembangannya di masa anak-anak dan mempengaruhi kualitas sumber daya manusia di masa yang akan datang. Tujuan: Penelitian ini bertujuan untuk mengetahui pengaruh integrasi intervensi gizi dan stimulasi tumbuh kembang terhadap peningkatan berat badan dan perkembangan pada balita kurus. Metode: Desain penelitian quasi-experimental with pre- and post-test control group yang dilakukan pada 38 subjek balita yang berada di Kecamatan Sedayu. Sampel dipilih berdasarkan total sampling balita yang berada di community feeding center dan kontrol adalah balita yang dijaring melalui posyandu-posyandu di desa yang berbeda dengan rasio 1:1. Intervensi paket edukasi, stimulasi tumbuh kembang, dan pemberian makanan tambahan-pemulihan (PMT-P) disampaikan melalui kader yang telah diberikan capacity building. Analisis yang digunakan adalah uji Mann-Whitney $U$ dan Wilcoxon Signed Rank pada tingkat kepercayaan 0,05. Hasil: Berat badan balita di kelompok intervensi antara sebelum $(9,17 \pm 1,89)$ dan setelah $(9,27 \pm 1,79)$ diberikan intervensi meningkat secara signifikan $(\mathrm{p}=0,04)$. Nilai gangguan perkembangan menurun dari skor $1,32 \pm 0,75$ menjadi $0,42 \pm 0,61(\mathrm{p}=0,00)$. Simpulan: Intervensi berupa paket edukasi tentang gizi dan perkembangan, stimulasi tumbuh kembang, dan PMT-P melalui community feeding center (CFC) dapat meningkatkan berat badan dan perkembangan balita kurus secara signifikan.
\end{abstract}

KATA KUNCI: berat badan; balita; stimulasi tumbuh kembang; intervensi gizi; PMT-P

Korespondensi: Bunga Astria Paramashanti, Program Studi Ilmu Gizi, Fakultas Ilmu-ilmu Kesehatan Universitas Alma Ata, Jl. Ringroad Barat Daya No. 1 Tamantirto, Bantul, Yogyakarta, 55183, Indonesia, Telp. +62 274434 2288, Fax. +62 274434 2269, e-mail: pshanti.bunga@gmail.com 


\section{PENDAHULUAN}

Indonesia mengalami masalah gizi transisi yaitu kejadian double-burden malnutrition semakin meningkat (1). Pada lingkup ibu dan anak, masalah gizi mencakup gizi kurang dan gizi lebih. Malnutrisi pada anak berkontribusi sebesar 35\% sebagai penyebab dari total kematian balita (2). Di sisi lain, malnutrisi memiliki dampak yang negatif pada perkembangan kognitif, performa akademik, dan produktivitas (3).

World Health Organization (WHO) menyatakan resolusi target global pada gizi ibu dan anak sebagai prioritas (3). Di Indonesia, prevalensi underweight pada tahun 2013 mencapai 19,6\% dan 5,7\% diantaranya menderita gizi buruk. Angka ini menunjukkan prevalensi yang meningkat dari tahun-tahun sebelumnya dengan 18,4\% di tahun 2007 dan 17,9\% di tahun 2010. Perubahan terutama terjadi pada prevalensi gizi buruk, yaitu dari sebesar 5,4\% pada tahun 2007 dan 4,9\% pada tahun 2010, menjadi 5,7\% di tahun 2013 (4). Hasil deteksi tumbuh kembang anak yang dilakukan di Jakarta pada 400 anak usia 0-6 tahun, ditemukan sebanyak 50 anak (12,5\%) dengan kelainan tumbuh kembang.

Dalam rangka mencapai potensi perkembangan, pemenuhan gizi, serta pencegahan dan pengobatan sakit yang optimal pada anak, diperlukan integrasi pelayanan kesehatan yang meliputi promosi kesehatan, gizi, dan stimulasi di usia dini. Pelayanan dan intervensi kesehatan sangat diperlukan untuk mendukung ibu dan anak dari segi kesehatan, gizi, sosial, emosional, dan perkembangan kognitif (5). Namun, pada kenyataannya intervensi dari sektor kesehatan memiliki keterbatasan dari segi implementasi akibat lemahnya sistem kesehatan. Salah satu contohnya adalah implementasi program kesehatan yang tidak terkoordinasikan dengan baik antar profesi kesehatan, serta ketidakjelasan peran dan tanggung jawab yang spesifik di antara tenaga-tenaga kesehatan (6).

Intervensi gizi dan perkembangan anak usia dini merupakan strategi yang baik dalam mendukung tumbuh kembang anak secara optimal, tetapi hanya sedikit penelitian yang dilakukan berbasis komunitas (7). Berdasarkan profil kesehatan Kabupaten Bantul, prevalansi gizi buruk tertinggi berada di Kecamatan Sedayu $(0,81 \%)(8)$. Selain itu, pada penelitian sebelumnya menunjukkan bahwa dari 100 anak usia bawah dua tahun (baduta) di Kecamatan Sedayu, ditemukan baduta yang mengalami gangguan perkembangan motorik (12\%), kognitif(10\%), bahasa (11\%), sosioemosional (33\%), dan adaptif (15\%) (9). Oleh karena itu, tujuan penelitian ini adalah ingin membuktikan pengaruh integrasi intervensi gizi dan stimulasi tumbuh kembang terhadap status gizi dan perkembangan balita kurus di Kecamatan Sedayu.

\section{BADAN DAN METODE}

Jenis penelitian yang digunakan adalah kuantitatif dengan desain penelitian eksperimental, yaitu quasiexperimental with pretest-posttest control group. Desain ini bertujuan untuk mengevaluasi intervensi dengan melihat sebab-akibat dari sebuah intervensi terhadap outcome penelitian, tetapi tidak menggunakan randomisasi. Pada penelitian ini, randomisasi tidak dimungkinkan karena beberapa alasan, yaitu hanya ada dua Community Feeding Center (CFC) di Kecamatan Sedayu sehingga tidak bisa merandomisasi berdasarkan lokasi, serta randomisasi subjek tidak dapat dilakukan karena alasan etika bahwa CFC tersebut telah memiki kriteria subjek tersendiri sesuai dengan sistem yang berjalan. Penelitian ini dilakukan pada bulan Januari September 2017 di CFC yang terletak di Desa Argodadi dan Desa Argorejo sebagai lokasi intervensi. Lokasi penelitian pada kelompok kontrol berada di posyanduposyandu di Desa Argosari dan Desa Argomulyo.

Populasi dalam penelitian ini adalah seluruh balita usia 0-59 bulan di Kecamatan Sedayu. Sampel adalah sebagian dari balita usia 0-59 bulan yang termasuk ke dalam sasaran CFC, yaitu balita yang berstatus gizi kurus (BB/TB <-2SD) dan berasal dari status ekonomi rendah. Kontrol dipilih dari posyandu yang ada di kecamatan yang sama dengan kecamatan tempat CFC berada. Total sampling dilakukan pada seluruh balita yang tergabung di CFC karena jumlah balita yang minimal yaitu 19 orang sedangkan kontrol diambil dari balita di posyandu dengan rasio jumlah 1:1 sehingga total sampel dalam penelitian ini adalah 38 orang. Seluruh sampel telah diberikan informed consent dengan persetujuan oleh orang tuanya. Penelitian ini mendapat persetujuan uji layak etik dengan nomor KE/AA/IV/147/EC/2017 dari Komite Etik Universitas Alma Ata. 
Intervensi yang diberikan berupa paket edukasi gizi kepada ibu balita dan stimulasi tumbuh kembang kepada balita di CFC yang diberikan oleh tenaga kesehatan dan kader yang telah mengikuti capacity building. Paket intervensi ini terdiri dari 8 sesi penyuluhan kelompok dan 8 sesi konseling individu dengan supervisi dari tim intervensi. Materi edukasi gizi terdiri dari pentingnya pemberian ASI eksklusif 6 bulan dan keberlanjutan ASI selama dua tahun, waktu pemberian MPASI; jumlah, frekuensi dan jenis dan makanan balita; dan contoh menu yang dimodifikasi dari panduan PAHO/WHO (10) dan Ditjen Bina Gizi-KIA Kemenkes RI (11), serta disesuaikan dengan angka kecukupan gizi (AKG) untuk balita Indonesia. Selain itu, pemberian makanan tambahan-pemulihan (PMT-P) juga didistribusikan berdasarkan program reguler yang ada di CFC. Pada kelompok kontrol, tidak ada intervensi yang diberikan selain program reguler yang ada di posyandu yang meliputi pemantauan berat badan melalui penimbangan rutin dan penyuluhan kelompok tentang kesehatan balita setiap sebulan sekali (12).

Instrumen pengumpulan data yang digunakan adalah kuesioner dan formulir deteksi dini tumbuh kembang. Formulir deteksi dini tumbuh kembang yang digunakan adalah kuesioner pra skrining perkembangan (KPSP) (13). Komponen perkembangan yang diukur meliputi perkembangan motorik halus, motorik kasar, bahasa, serta sosial, dan kemandirian. Pengambilan data perkembangan dengan KPSP dilakukan oleh dua orang mahasiswa Sarjana Ilmu Keperawatan tingkat akhir yang telah dilatih sebelumnya. Hasil rekapitulasi skor gangguan perkembangan dihitung berdasarkan tingkatan skor, yaitu 0 jika perkembangan sesuai; 1 jika perkembangan meragukan; dan 2 jika perkembangan menyimpang. Data berat badan diambil dengan menggunakan timbangan berat badan sedangkan panjang badan menggunakan alat ukur panjang badan (length board). Kuesioner yang digunakan sebelumnya telah teruji validitas dan reliabilitasnya.

Analisis data yang digunakan meliputi deskriptif untuk menggambarkan karakteristik partisipan. Perbedaan antara kelompok intervensi dan kelompok kontrol dianalisis dengan menggunakan independent t-test sedangkan perubahan sebelum dan sesudah perlakuan diketahui menggunakan uji Mann-Whitney U test. Seluruh analisis tersebut menggunakan tingkat signifikansi 0,05.

\section{HASIL}

Kecamatan Sedayu merupakan salah satu kecamatan di Kabupaten Bantul yang menjadi prioritas kedua untuk prevalensi balita bawah garis merah (berlabel kuning) berdasarkan Profil Kesehatan Kabupaten Bantul tahun 2017. Kecamatan Sedayu memiliki dua Pusat Pemulihan Gizi Berbasis Masyarakat (community feeding center atau CFC). Kedua CFC ini dikelola oleh Puskesmas Sedayu 2 dengan dana penyelenggaraan yang berasal dari Anggaran Pendapatan dan Belanja Daerah (APBD). Program reguler CFC menyediakan pemberian makanan tambahan-pemulihan (PMT-P) berbasis pangan lokal selama 90 hari, pengukuran status gizi, dan penyuluhan kelompok. Kegiatan yang dijadwalkan seminggu sekali ini melibatkan tenaga kesehatan seperti dokter, bidan, dan ahli gizi, serta kader-kader posyandu. Sasaran dari program CFC adalah balita berstatus gizi kurus (skor z BB/TB <-2 SD - (-3.00) SD). Apabila APBD terbatas, maka balita yang berasal dari keluarga miskin akan diprioritaskan terlebih dahulu.

\section{Karakteristik partisipan}

Total balita yang menjadi sasaran dari CFC berjumlah 19 balita sehingga kelompok kontrol yang diambil juga berjumlah 19 balita. Berdasarkan Tabel 1, diketahui bahwa sebagian besar balita di kelompok intervensi berjenis kelamin laki-laki $(63,2 \%)$ sedangkan

Tabel 1. Karakteristik balita dan ibu balita

\begin{tabular}{lcc}
\hline \multirow{2}{*}{ Karakteristik } & \multicolumn{2}{c}{ Kelompok } \\
\cline { 2 - 3 } & Intervensi & Kontrol \\
\hline Jenis kelamin balita (n (\%)) & $7(36,8)$ & $12(63,2)$ \\
Perempuan & $12(63,2)$ & $7(36,8)$ \\
Laki-laki & $29,6 \pm 14,3$ & $37,0 \pm 14,3$ \\
Usia balita, bulan (rerata \pm SD) & $32,4 \pm 5,5$ & $31,32 \pm 4,4$ \\
Usia ibu, tahun (rerata \pm SD) & & \\
Tingkat pendidikan ibu (n (\%)) & & \\
Tamat SD & $4(21,1)$ & $2(10,5)$ \\
Tamat SMP & $5(26,3)$ & $8(42,1)$ \\
Tamat SMA & $9(47,4)$ & $9(47,4)$ \\
Tamat perguruan tinggi & $1(5,3)$ & $0(0)$ \\
\hline
\end{tabular}


Tabel 2. Perubahan berat badan dan skor perkembangan

\begin{tabular}{|c|c|c|c|}
\hline \multirow[b]{2}{*}{ Variabel } & \multicolumn{2}{|c|}{ Rerata \pm SD } & \multirow[b]{2}{*}{ Nilai $p$} \\
\hline & $\begin{array}{c}\text { Intervensi } \\
(\mathrm{n}=19)\end{array}$ & $\begin{array}{c}\text { Kontrol } \\
(\mathrm{n}=19)\end{array}$ & \\
\hline \multicolumn{4}{|c|}{ Berat badan $(\mathrm{kg})$} \\
\hline Sebelum & $9,17 \pm 1,89$ & $13,04 \pm 3,56$ & $0,00^{*}$ \\
\hline Sesudah & $9,27 \pm 1,79$ & $13,11 \pm 3,50$ & $0,00^{*}$ \\
\hline Nilai $\mathrm{p}$ & $0,04 *$ & $0,03 *$ & \\
\hline \multicolumn{4}{|c|}{ Skor gangguan perkembangan } \\
\hline Sebelum & $1,32 \pm 0,75$ & $0,84 \pm 0,90$ & 0,09 \\
\hline Sesudah & $0,42 \pm 0,61$ & $0,68 \pm 0,82$ & 0,27 \\
\hline Nilai $p$ & $0,00^{*}$ & 0,083 & \\
\hline
\end{tabular}

sebagian besar balita di kelompok kontrol berjenis kelamin perempuan $(63,2 \%)$. Rerata usia balita di kelompok intervensi dan kelompok kontrol masingmasing adalah 29,6 bulan dan 37 bulan. Pada variabel usia ibu, antara kelompok intervensi dan kelompok kontrol tidak jauh berbeda dengan rerata 32 dan 31 tahun. Tingkat pendidikan ibu di kedua kelompok sebagian besar adalah tamat SMA $(47,4 \%)$.

\section{Analisis bivariabel}

Tabel 2 menunjukkan perubahan berat badan dan skor perkembangan balita antara kelompok intervensi dan kelompok kontrol. Pada awal penelitian, data berat badan pada kelompok intervensi dan kelompok kontrol berbeda. Hal ini kemungkinan disebabkan oleh kriteria admisi program CFC dan posyandu yang berbeda, yaitu balita yang dipilih pada program $\mathrm{CFC}$ adalah balita kurus (skor $\mathrm{Z} \mathrm{BB/TB}<-2 \mathrm{SD}$ ). Rerata berat badan pada kelompok intervensi sebelum $(9,17 \pm 1,89 \mathrm{~kg})$ dan setelah $(9,27 \pm 1,79 \mathrm{~kg})$ intervensi menunjukkan perbedaan. Kelompok intervensi $(\mathrm{p}=0,04)$ dan kelompok kontrol $(\mathrm{p}=0,03)$ sama-sama mengalami kenaikan berat badan. Meskipun demikian, peningkatan berat badan pada kelompok intervensi $(0,1 \mathrm{~kg})$ menunjukkan kenaikan yang lebih besar daripada kelompok kontrol $(0,07 \mathrm{~kg})$.

Rerata skor gangguan perkembangan pada kelompok intervensi sebelum perlakuan yaitu sebesar $1,32 \pm 0,75$. Artinya, balita memiliki perkembangan yang tidak sesuai. Setelah diberi perlakuan, rerata skor gangguan perkembangan pada kelompok intervensi menurun menjadi $0,42 \pm 0,61$. Penurunan skor gangguan perkembangan pada kelompok intervensi ini menunjukkan hasil yang signifikan $(\mathrm{p}=0,00)$. Di sisi lain, perubahan skor gangguan perkembangan pada kelompok kontrol tidak menunjukkan penurunan yang bermakna $(\mathrm{p}=0,083)$.

\section{BAHASAN}

Hasil analisis bivariabel menunjukkan adanya peningkatan berat badan setelah intervensi. Hal ini membuktikan adanya pengaruh dari paket pemberian edukasi tentang gizi dan perkembangan, serta PMT-P terhadap berat badan balita kurus. Namun, hal yang sama juga terjadi pada kelompok kontrol yaitu balita kelompok kontrol juga mengalami peningkatan berat badan yang menunjukkan bahwa program regular juga memberikan dampak yang positif. Tetapi, peningkatan berat badan balita pada kelompok intervensi lebih besar dibandingkan dengan kelompok kontrol dengan selisih rerata sebesar $300 \mathrm{~g}$.

Sebanyak 16 penelitian sejenis sebelumnya dengan desain eksperimental berhasil meningkatkan berat badan, tetapi tidak signifikan sedangkan peningkatan berat badan yang signifikan tercatat pada populasi yang tahan pangan (food secure) (14). Hasil ini mempertegas bahwa populasi pada penelitian ini tergolong dalam kategori tidak tahan pangan (food insecure) yang masalahnya tidak dapat diatasi dengan pemberian paket integrasi edukasi saja karena masalah dasarnya adalah keterbatasan kemampuan ekonomi, seperti studi yang dilaporkan di Nepal bahwa rumah tangga yang tidak tahan pangan memiliki akses yang rendah terhadap suplai makanan (15).

Tidak ada perbedaan skor gangguan perkembangan yang bermakna $(\mathrm{p}=0,09)$ antara kelompok intervensi (rerata $=1,32)$ dengan kelompok kontrol (rerata $=0,89$ ), yang artinya sebaran keduanya homogen. Melalui pemberian intervensi, balita mengalami penurunan skor gangguan perkembangan secara signifikan yaitu rerata skor menjadi 0,42 yang menunjukkan adanya efek intervensi pada perbaikan perkembangan balita. Berbeda dengan balita di kelompok kontrol yang mendapatkan program posyandu secara regular, tidak mengalami peningkatan skor perkembangan secara bermakna.

Sebuah penelitian di Bangladesh menunjukkan bahwa setelah diberikan stimulasi dan suplementasi makanan, terjadi peningkatan perkembangan pada bayi 
dan anak. Hasil tersebut memberikan simpulan bahwa program yang merubah perilaku yang berfokus pada praktik stimulasi dan praktik makan memberikan manfaat yang positif terhadap status gizi dan perkembangan anak (16). Integrasi intervensi gizi dan perkembangan dapat dimulai sejak dini, yaitu pada 1000 hari pertama kehidupan yang merupakan masa kritis anak untuk meraih potensinya (17). Dukungan keluarga dari segala aspek sangat penting diberikan, terlebih lagi bagi anak-anak yang perkembangannya memang terhambat, mereka sangat membutuhkan dukungan dari keluarga dalam memberikan zat gizi adekuat untuk mendukung tumbuh kembangnya (18).

Anak-anak yang diberikan zat gizi adekuat dan kesempatan untuk pembelajaran dini memiliki kesempatan yang baik dalam tumbuh kembangnya (19). Kombinasi intervensi gizi dan stimulasi pada balita terbukti cost-effective, terlebih jika melibatkan kaderkader yang ada di masyarakat (20). Selanjutnya, kader mengedukasi dan mengajarkan ibu atau pengasuh utama bagaimana menyediakan makanan yang bergizi, cara memberikan makanan, dan bermain secara responsif. Sejalan dengan penelitian yang telah dilakukan di daerah pedesaan India, intervensi berbasis masyarakat seperti ini dapat meningkatkan asupan makan, pertumbuhan, dan perkembangan anak (21).

Penelitian ini memiliki beberapa kelemahan, yaitu jumlah sampel yang relatif sedikit meskipun sudah dilakukan total sampling. Selain itu, tidak semua karakteristik subjek antara kelompok intervensi dan kontrol homogen di awal penelitian sehingga mengaburkan efek dari intervensi yang diberikan. Meskipun begitu, penelitian ini memiliki beberapa kelebihan antara lain intervensi yang diberikan merupakan integrasi dari intervensi gizi dan stimulasi tumbuh kembang sehingga dapat mengatasi permasalahan gizi dan perkembangan balita kurus dari berbagai sisi. Selain itu, intervensi juga disampaikan oleh kader yang sebelumnya telah dibekali dengan capacity building tentang gizi dan perkembangan balita. Selama ini, beban kerja kader memang besar, tetapi dengan adanya dukungan yang kuat maka akan mensukseskan implementasi intervensi yang diberikan (19). Ditambah lagi, kader yang telah dibekali tersebut dapat melanjutkan intervensi yang diberikan bahkan setelah penelitian berakhir. Selanjutnya, monitoring, evaluasi, dan pelatihan secara berkala menjadi tantangan yang harus dilaksanakan untuk keberlangsungan intervensi.

\section{SIMPULAN DAN SARAN}

Berat badan dan perkembangan balita kurus yang diberikan intervensi berupa paket edukasi tentang gizi dan perkembangan, stimulasi tumbuh kembang, dan PMT-P melalui community feeding center (CFC) meningkat secara signifikan. Integrasi intervensi gizi dan stimulasi tumbuh kembang dapat menjadi prioritas dalam rangka mengatasi masalah gizi dan tumbuh kembang pada balita. Beban kerja kader memang besar sehingga peningkatan kapasitas kader (capacity building) sebaiknya dilakukan secara berkala dalam rangka mencapai status gizi dan kesehatan yang optimal dan berkelanjutan. Demikian pula, monitoring, evaluasi, dan pelatihan secara berkala perlu dilaksanakan untuk keberhasilan upaya intervensi.

\section{Pernyataan konflik kepentingan}

Tidak ada konflik kepentingan dalam penelitian ini.

\section{UCAPAN TERIMA KASIH}

Tim peneliti mengucapkan terima kasih pada Kementrian Riset, Teknologi, dan Pendidikan Tinggi Republik Indonesia atas pendanaan yang diberikan pada penelitian ini.

\section{RUJUKAN}

1. Shrimpton R, Rokx C. The double burden of malnutrition in Indonesia. [series online] 2013 [cited 2017 Dec 13]. Available from: URL: http://documents.worldbank.org/ curated/en/955671468049836790/pdf/761920WP0P126 40Box0379884B00PUBLIC0.pdf

2. Black RE, Victora CG, Walker SP, Bhutta ZA, Christian $\mathrm{P}$, De Onis M, et al. Maternal and child undernutrition and overweight in low-income and middle-income countries. Lancet 2013;382(13):427-51.

3. Jones AD, Ickes SB, Smith LE, Mbuya MNN, Chasekwa B, Heidkamp RA, et al. World Health Organization infant and young child feeding indicators and their associations 
with child anthropometry: a synthesis of recent findings. Matern Child Nutr 2014;10:1-17.

4. World Health Organization (WHO). Proposed global targets for maternal, infant and young child nutrition. [series online] 2012 [cited 2017 Dec 13]. Available from: URL: http://www.who.int/nutrition/events/2012 proposed_globaltargets_backgroundpaper.pdf

5. Kementrian Kesehatan RI. Laporan riset kesehatan dasar 2013. [series online] 2013 [cited 2017 Sep 11]. Available from: URL: http://www.depkes.go.id/resources/download/ general/Hasil Riskesdas 2013.pdf

6. Yousafzai AK, Rasheed MA, Rizvi A, Armstrong R, Qar Z, Bhutta A. Effect of integrated responsive stimulation and nutrition interventions in the Lady Health Worker programme in Pakistan on child development, growth, and health outcomes: a cluster-randomised factorial effectiveness trial. Lancet [series online] 2014 [cited 2017 Oct 24];384(9950):1282-93. Available from: URL: http://www.thelancet.com/pdfs/journals/lancet/PIIS01406736(14)60455-4.pdf

7. Fernandez-Rao S, Hurley KM, Nair KM, Balakrishna N, Radhakrishna K V, Black MM, et al. Integrating nutrition and early child-development interventions among infants and preschoolers in rural India. Ann N Y Acad Sci 2014;1308:218-31.

8. Dinas Kesehatan Kabupaten Bantul. Profil kesehatan Kabupaten Bantul 2016. [series online] 2016 [cited 2017 Oct 9]. Available from: URL: http://dinkes.bantulkab. go.id/filestorage/dokumen/2016/08/narasi profil 2016.pdf

9. Pantaleon MG, Hadi H, Gamayanti IL. Stunting berhubungan dengan perkembangan motorik anak di Kecamatan Sedayu, Bantul, Yogyakarta. J Gizi dan Dietetik Indones 2015;3(1):10-21.

10. PAHO/WHO. Guiding principle for complementary feeding of the breastfed children. [series online] 2003 [cited 2017 Oct 9]. Available from: URL: https://www. who.int/nutrition/publications/guiding_principles_ compfeeding_breastfed.pdf

11. Ditjen Bina Gizi dan Kesehatan Ibu dan Anak. Panduan penyelenggaraan pemberian makanan tambahan pemulihan bagi balita gizi kurang (bantuan operasional kesehatan). [series online] 2011 [cited 2017 Dec 19]. Available from: URL: http://gizi.depkes.go.id/wp-content/ uploads/2011/11/Panduan-PMT-BOK.pdf

12. Kementerian Kesehatan RI. Ayo ke POSYANDU. [series online] 2012 [cited 2018 Dec 18]. Available from: URL: http://www.promkes.depkes.go.id
13. Kementerian Kesehatan RI. Pedoman pelaksanaan stimulasi, deteksi dan intervensi dini tumbuh kembang anak. Jakarta: Kemenkes RI; 2016.

14. Lassi ZS, Das JK, Zahid G, Imdad A, Bhutta ZA. Impact of education and provision of complementary feeding on growth and morbidity in children less than 2 years of age in developing countries: a systematic review. BMC Public Health 2013;13(Suppl 3):S13.

15. Osei A, Pandey P, Spiro D, Nielson J, Shrestha R, Talukder $\mathrm{Z}$, et al. Household food insecurity and nutritional status of children aged 6 to 23 months in Kailali District of Nepal. Food Nutr Bull [series online] 2010 [cited 2017 Dec 19];31(4):48394. Available from: URL: http://www.ingentaconnect.com/ content/nsinf/fnb/2010/00000031/00000004/art00002

16. Aboud FE, Akhter S. A cluster-randomized evaluation of a responsive stimulation and feeding intervention in Bangladesh. Pediatrics [series online] 2011 [cited 2017 Sep 8];127(5):e1191-7. Available from: URL: http://pediatrics. aappublications.org/cgi/doi/10.1542/peds.2010-2160

17. Maalouf-Manasseh Z, Oot L, Sethuraman K. Giving children the best start in life: integrating nutrition and early childhood development programming within the first 1,000 days. [series online] 2016 [cited 2017 Sep 8]. Available from: URL: https:// www.fantaproject.org/sites/default/files/resources/NutritionEarly-Childhood-Development-Technical-Brief-Jan2016.pdf

18. Paramashanti BA, Rakhman A, Endriyani L. Dukungan keluarga berhubungan dengan asupan energi anak retardasi mental di SLB Negeri 01 Kabupaten Bantul. J Ners dan Kebidanan Indones 2016;4(3):163-8.

19. Black MM, Perez-Escamilla R, Fernandez Rao S. Integrating nutrition and child development interventions: scientific basis, evidence of impact, and implementation considerations. Adv Nutr An Int Rev J [series online] 2015 [cited 2017 Sep 8];6(6):852-9. Available from: URL: http://advances. nutrition.org/cgi/doi/10.3945/an.115.010348

20. Gowani S, Yousafzai AK, Armstrong R, Bhutta ZA. Cost effectiveness of responsive stimulation and nutrition interventions on early child development outcomes in Pakistan. Ann N Y Acad Sci. 2014;1308(1):149-61.

21. Vazir S, Engle P, Balakrishna N, Griffiths PL, Johnson $\mathrm{SL}$, Creed-Kanashiro H, et al. Cluster-randomized trial on complementary and responsive feeding education to caregivers found improved dietary intake, growth, and development among rural Indian toddlers. Matern Child Nutr [series online] 2013 [cited 2017 Oct 10];9(1):99-117. Available from: URL: https://www.ncbi.nlm.nih.gov/pmc/ articles/PMC3434308/pdf/nihms365899.pdf 